\title{
光独立栄養条件および光混合栄養条件下で培養された アルファルファ小植物体の生長および光合成速度
}

\author{
谷晃·清田 信 - 平 知 明 - 相 賀一 郎 \\ 大阪府立大学農学部
}

Growth and Photosynthesis of Alfalfa Plantlets Cultured in vitro under Photoautotrophic and Photomixotrophic Condition

\author{
Akira Tani, Makoto Kiyota, Tomoaki Taira and Ichiro Aiga \\ College of Agriculture, University of Osaka Prefecture, Sakai 591, Japan
}

\begin{abstract}
In order to clarify the differences in growth characteristics between photoautotrophically and photomixotrophically grown plantlets, growth rate and net photosynthetic rate $\left(P_{\mathrm{N}}\right)$ of alfalfa plantlets were measured. These plantlets were cultured in vitro on hormone-free MS medium with different sucrose concentrations of 0,1 and $3 \%$ in aerated vessels.

Chlorophyll content per unit leaf area of plantlets with $1 \%$ sucrose was the greatest $(61 \pm 2$ $\left.\mu \mathrm{g} \cdot \mathrm{cm}^{-2}\right)$ at all times $(7,14$ and 21 days after treatments). Leaf area with $1 \%$ sucrose was 1.4 times greater than that with $0 \% 14$ and 21 days after treatments. But that with $3 \%$ was lower. $P_{\mathrm{N}}$ values per unit leaf area with 0 and $1 \%$ sucrose were similar to each other. While those with $3 \%$ sucrose did not increase from the start of treatments and much lower than those with $0 \%$.

These results suggest that photomixotrophic condition with optimal concentration of sucrose accelerate the growth of photosynthetic organs and enable alfalfa plantlets to acquire photosynthetic products, at least, as much as those acquired under photoautotrophic condition.
\end{abstract}

(Received March 28, 1991)

1991 年 3 月 28 日受付

\section{はじめに}

小植物体の組織培養において, 培養器内のガス環境を 改善し小植物体の光合成を促進させる条件下では，培地 に糖を含まない無糖培養法が適していると古在らによっ て指摘されている1). 無糖培養の利点としては，糖によ る生理的ストレスを培養物に与えない，微生物による污 染の減少，作業の簡易性などがあげられる.

しかし，小植物体の生育促進という点について考える

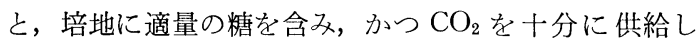
た光混合栄養条件で，光独立栄養条件と同様 ${ }^{2}$ かあるい はそれより高い生長量 ${ }^{3,4)}$ が得られている.これらの小 植物体は光混合栄養条件下で, 培地の糖と空気中の $\mathrm{CO}_{2}$
の両方を炭素源として生長している.

ところで，光混合栄養条件および光独立栄養条件下で 生長する培養小植物体の光合成速度についての報告はわ ざかにみられる ${ }^{5,6)}$ だけであり, 培地のショ糖および光 独立栄養生長を促進する光, $\mathrm{CO}_{2}$ が小植物体の光合成や 生長に与える複合的な影響について検討する必要があ る.

そこで, 本研究では培養器内へ通気する方法を用いて, 光独立栄養生長を促進する条件下で, 培地に与えられた ショ糖が，アルファルファ小植物体の同化器官の生長や 光合成活性に与える影響について調査し, 光独立栄養生 長と光混合栄養生長の生育特性の差違を比較した。 


\section{材料および方法}

\section{1. 培養方法}

供趾材料としてアルファルファ (Medicago sativa L. cv. Du Puits）を用い，その実生の切除茎を外植体とし て得た. まず, 種子を $1.5 \%$ の次亜塩素酸ナトリウムに 10 分間浸漬滅菌し, 植物培養用容器 (植物組織培養 PC ビン, 大日本プラスチック製：以下培養器と呼ぶ）内の ショ糖濃度が $3 \%$ の MS 培地 7 に置床した. 培養器は, 底面積 $100 \mathrm{~cm}^{2}$, 容積 $1,000 \mathrm{~cm}^{3}$ のポリカーボネイト製で あった。

培養器内の種子は $25^{\circ} \mathrm{C}$, 暗黒の条件下で発芽し, 子 葉を展開した。播種 4 日後, 培養器を $25^{\circ} \mathrm{C}$, 光照射の 条件下へ移した. 光源には, 冷白色蛍光灯 $(40 \mathrm{~W}$, 日立 製）を用い, 24 時間連続照明下で 25 日間培養した。培養 器内の植物体葉面での光合成有効光量子束密度 (PPFD) は, $90 \mu \mathrm{mol} \cdot \mathrm{m}^{-2} \cdot \mathrm{sec}^{-1}$ であった．播種から実生の培養 が終了するまで培養器は無通気の状態であり, 培養器の 換気回数は 0.5 回· $\mathrm{hr}^{-1}$ であった.

25 日間の培養後, 実生の茥を 2 枚の葉を付けて切除 し，外植体を得た．外植体の生重は $90 \pm 10 \mathrm{mg}$ であっ た.これらの外植体を植物材料として, ショ糖濃度がそ れぞれ 0,1 ，および $3 \%$ の MS 培地を含む培養器に 4 個体ずつ植え付け処理を開始した. 用いた培養器および 温度, 光の条件は実生の培養と同じであったが，培養器 内へは，プレフィルター（ミリポア社製）および綿で滤 過した無菌空気を通気した。通気量は $0.2 l \cdot \mathrm{min}^{-1}, \mathrm{CO}_{2}$ 濃度は $340 \mathrm{ppm}$ に設定した。培養器内の湿度は, 水中で バブリングした空気を通気することによって 85〜90\% に保った。

なお，培地は滅菌する前に $1 \mathrm{~N}$ の $\mathrm{HCl}$ または $\mathrm{NaOH}$ で $\mathrm{pH} 6.0$ に調整し， $0.2 \%$ のジェルライト（ジェラン ガム, 三栄化学工業) を加光て, $100 \mathrm{ml}$ ずつ培養器に分 注した。培地の滅菌は，オートクレイブ (1.2 気圧, 30 分間）で行った。

\section{2. 光合成速度の測定}

光合成速度および暗呼吸速度の測定は，処理開始時お よび 7，14，21 日目に培養器をグロースチャンバー（光 源：白熱ランプ, 䖢光水銀ランプ, 䖺光ランプの混合光) 内へ移して行った. $\mathrm{CO}_{2}$ 濃度の測定は赤外線ガス分析計 (ZALDA，富士電機製）を用いて，開放式同化箱法で行 った．同化箱として培養器をとのまま用い，蓋に 2 本の 塩ビチューブを取り付け，一方のチューブから $\mathrm{CO}_{2}$ 濃 度が $340 \mathrm{ppm}$ の空気を通気し，他方のチューブから排 出した.
測定は， PPFD が $100 \mu \mathrm{mol} \cdot \mathrm{m}^{-2} \cdot \mathrm{sec}^{-1}, \quad 300 \mu \mathrm{mol}$. $\mathrm{m}^{-2} \cdot \mathrm{sec}^{-1}$ および暗黒の光条件下で行い, 培養器入り口 と出口の $\mathrm{CO}_{2}$ 濃度差 $\Delta C_{\mathrm{P}}(\mathrm{ppm})$ を測定した後, 小植物 体の地上部 (茎葉部) を切除し地下部（根部）の久を残 し，暗黑下での $\mathrm{CO}_{2}$ 濃度差 $\Delta C_{\mathrm{R}}(\mathrm{ppm})$ を測定した. 次 に根を抜き取り寒天だけの $\mathrm{CO}_{2}$ 濃度差 $\Delta C_{\mathrm{G}}(\mathrm{ppm})$ を求 めた.

小植物体地上部当りの純光合成速度 $P_{\mathrm{N}}\left(\mathrm{mgCO}_{2}\right.$. $\left.\mathrm{shoot}^{-1} \cdot \mathrm{hr}^{-1}\right)$ は，以下の式に代入して求めた ${ }^{8)}$.

$$
\begin{aligned}
P_{\mathrm{N}}= & \frac{44 \times 10^{3}}{22.4} \times\left(\Delta C_{\mathrm{P}}-\Delta C_{\mathrm{R}}\right) \\
& \times 10^{-6} \times V \times 60 \times \frac{273}{273+T} \times \frac{1}{N}
\end{aligned}
$$

ここで, $V\left(l \cdot \mathrm{min}^{-1}\right)$ は培養器への通気量, $T\left({ }^{\circ} \mathrm{C}\right)$ は培 養器内の気温, $N$ は培養器内の小植物体数である. ただ し小植物体が発根していない場合は, 上式の $\Delta C_{\mathrm{R}}$ の代 りに $\Delta C_{\mathrm{G}}$ を用いた。

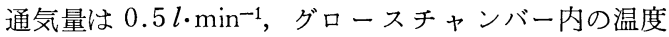
は $25 \pm 2{ }^{\circ} \mathrm{C}$ に設定した. 各測定日に，処理区当り培養 器 4〜5 個ずつを測定に用い, 計 $16 \sim 20$ 個の小植物体の 平均值を求めた。

\section{3. 生長量の測定}

光合成測定に用いた小植物体の地上部生重, 発根植物 体数, 地下部生重, 葉面積方よび葉部のクロロフィル量 を測定した。葉面積は, 3 種類の形状と 10 段階の大きさ に区分けした面積計測用型紙を用い，それらに該当する 葉の個数を記録することによって求めた. 葉部のクロロ フィル量は, $80 \%$ アセトンで抽出し, 波長 645 および $663 \mathrm{~nm}$ での吸光度を分光光度計 (U-BEST50, 日本分 光製）を用いて测定し，その值を $A^{2} n n^{9)}$ の式に代入し て求めた.

\section{結果}

\section{1. 培地のショ糖濃度と光合成速度}

Table 1 に，小植物体地上部当りの光合成速度および 喑呼吸速度の経日変化を示す. 光合成速度は, PPFD が $100 \mu \mathrm{mol} \cdot \mathrm{m}^{-2} \cdot \mathrm{sec}^{-1}, 300 \mu \mathrm{mol} \cdot \mathrm{m}^{-2} \cdot \mathrm{sec}^{-1}$ のいずれの条 件下でも, 各ショ糖濃度区で処理後日数の経過とともに 増加した．光独立栄養生長区の $0 \%$ 区と比較して，1\% 区での光合成速度は, 14 日目に PPFD $100 \mu \mathrm{mol} \cdot \mathrm{m}^{-2}$. $\mathrm{sec}^{-1}$ で 1.4 倍 $\left(1.04 \mathrm{mgCO} \cdot \mathrm{shoot}^{-1} \cdot \mathrm{hr}^{-1}\right), 300 \mu \mathrm{mol}$. $\mathrm{m}^{-2} \cdot \mathrm{sec}^{-1}$ で 1.5 倍 $\left(1.83 \mathrm{mgCO} 2 \cdot \operatorname{shoot}^{-1} \cdot \mathrm{hr}^{-1}\right)$ になっ た。すた，ショ糖濃度 $3 \%$ 区での光合成速度は，0\%区 の $0.5 〜 0.9$ 倍であった.

一方，暗呼吸速度も日数の経過とともに増加したが， 生物環境調節 (Environ. Control in Biol.) 
Table 1 Net photosynthetic rate $\left(P_{\mathrm{N}}\right)$ per shoot of alfalfa plantlets cultured in vitro with different concentrations of sucrose in the medium.

\begin{tabular}{ccccc}
\hline \multirow{2}{*}{$\begin{array}{c}\text { PPFD } \\
\left(\mu \mathrm{mol} \cdot \mathrm{m}^{-2} \cdot \mathrm{sec}^{-1}\right)\end{array}$} & $\begin{array}{c}\text { Sucrose } \\
\text { concentration } \\
(\%)\end{array}$ & 7 & Net photosynthetic rate, $P_{\mathrm{N}}\left(\mathrm{mgCO}_{2} \cdot \mathrm{shoot}^{-1} \cdot \mathrm{hr}^{-1}\right)$ \\
\cline { 3 - 5 } & 0 & $0.55 \pm 0.01^{*}$ & $0.73 \pm 0.07$ & 21 \\
\hline \multirow{2}{*}{100} & 1 & $0.61 \pm 0.03$ & $1.04 \pm 0.13$ & $1.05 \pm 0.18$ \\
& 3 & $0.25 \pm 0.06$ & $0.43 \pm 0.16$ & $0.49 \pm 0.06$ \\
\hline \multirow{2}{*}{300} & 0 & - & $1.23 \pm 0.11$ & $1.82 \pm 0.20$ \\
& 1 & - & $1.83 \pm 0.26$ & $2.12 \pm 0.29$ \\
& 3 & - & - & $1.06 \pm 0.17$ \\
\hline \multirow{2}{*}{ Dark } & 0 & $-0.14 \pm 0.04$ & $-0.26 \pm 0.01$ & $-0.26 \pm 0.01$ \\
& 1 & $-0.15 \pm 0.02$ & $-0.27 \pm 0.04$ & $-0.48 \pm 0.03$ \\
& 3 & $-0.15 \pm 0.02$ & $-0.21 \pm 0.03$ & $-0.26 \pm 0.05$ \\
\hline
\end{tabular}

$P_{\mathrm{N}}$ was measured under PPFD of 0 (dark), 100 and $300 \mu \mathrm{mol} \cdot \mathrm{m}^{-2} \cdot \mathrm{sec}^{-1}$.

* Standard error, $n=4 \sim 5$.

Table 2 Chlorophyll (Chl) content per unit leaf area of alfalfa plantlets cultured in vitro with different concentrations of sucrose in the medium.

\begin{tabular}{clccc}
\hline \multirow{2}{*}{$\begin{array}{c}\text { Sucrose } \\
\text { concentration } \\
(\%)\end{array}$} & \multicolumn{4}{c}{ Chl content $\left(\mu \mathrm{gChl} \cdot \mathrm{cm}^{-2}\right)$} \\
\cline { 2 - 5 } & 7 & \multicolumn{4}{c}{ Days after treatments } \\
\hline 0 & $50 \pm 4 *$ & $47 \pm 8$ & $57 \pm 3$ & $50^{\mathrm{b}}$ \\
1 & $59 \pm 8$ & $63 \pm 4$ & $62 \pm 3$ & $61^{\mathrm{a}}$ \\
3 & $41 \pm 5$ & $44 \pm 8$ & $53 \pm 7$ & $47^{\mathrm{b}}$ \\
\hline
\end{tabular}

Different letters indicate significant difference at $5 \%$ level in $t$ test.

* Standard error, $n=4 \sim 5$.

処理 7 日目では, 培地のショ糖濃度にかかわりなく $-0.14 \sim-0.15 \mathrm{mgCO}_{2} \cdot \mathrm{shoot}^{-1} \cdot \mathrm{hr}^{-1}$ と同様な值であっ た(Table 1).しかし，処理 21 日目になると，1\%区で $-0.48 \mathrm{mgCO}_{2} \cdot \mathrm{shoot}^{-1} \cdot \mathrm{hr}^{-1}$ と著しく高い值を示した。

\section{2. 培地のショ糖濃度と生長量}

\section{2-1. クロロフィル含量および菓面積}

培養器内に植え付けられた外植体は, 数日後葉腋から シュートを伸長させて生長した．Table 2 に，単位葉面 積当りのクロロフィル含量の変化および平均值を示す. 単位葉面積当りのクロロフィル含量は, 処理開始時 $28 \mu \mathrm{g} \cdot \mathrm{cm}^{-2}$ であったが，7日目には，41〜 $59 \mu \mathrm{g} \cdot \mathrm{cm}^{-2}$ と高くなった。ショ糖濃度 $1 \%$ 区では，7日目に $59 \mu \mathrm{g}$. $\mathrm{cm}^{-2}$, それ以降も $62 \sim 63 \mu \mathrm{g} \cdot \mathrm{cm}^{-2}$ と処理区中最も高く なり，全測定日の平均值では $5 \%$ 水準で $0 \%$ 区と比較し

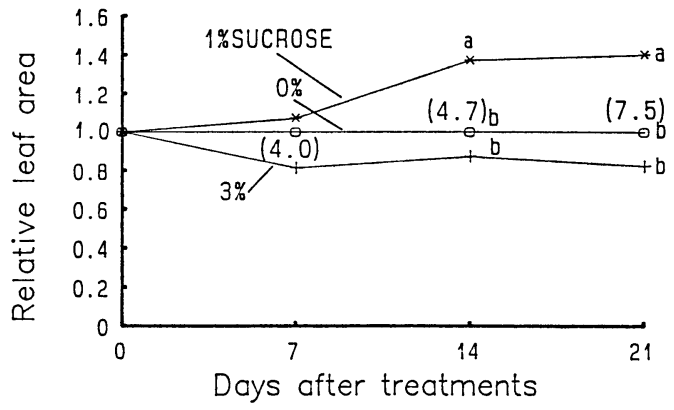

Fig. 1 Leaf area of alfalfa plantlets cultured in vitro with different concentrations of sucrose in the medium.

Each value is relative to that with $0 \%$ sucrose $(=100 \%)$ same days after treatments. Values in parentheses indicate leaf area $\left(\mathrm{cm}^{2} \cdot\right.$ shoot $\left.^{-1}\right)$ with $0 \%$ sucrose. Different letters indicate significant difference at $5 \%$ level in $t$ test.

て有意差が認められた。0\%区および3\%区では，処理 後の日数の経過とともに值は増加し，0\%区では 21 日目 になって $57 \mu \mathrm{g} \cdot \mathrm{cm}^{-2}$ と $1 \%$ 区の值に近づいた。 また， 3\% 区では葉のクロロシスがみられたが，クロロフィル 含量は $0 \%$ 区と比べて有意差が認められなかった。

小植物体当りの葉面積も, 培地のショ糖濃度に左右さ れ，処理 14 日目には明確な差を示した (Fig. 1).ショ 糖濃度 $0 \%$ 区における葉面積は, 日数の経過とともに増 加し，21日目には $7.5 \mathrm{~cm}^{2}$ となった。 $0 \%$ 区の值に対す 
る相対值を用いて $1 \%$ 区における葉面積を表すと， 7 日 目には増加は認められなかったが，14 日目になると 1.4 倍と有意な増加を示し $(p<0.05), 21$ 日目でも同様な 值となった.しかし, ショ糖濃度 $3 \%$ 区における葉面積 は，各測定日とも $0 \%$ 区の 0.8 倍であった。

\section{2-2. 生重, $S / R($ shoot/root) 比および発根率}

小植物体当りの生重については, 処理 21 日目に培地 のショ糖濃度間で明白な違いが認められた (Fig. 2). シ ヨ糖濃度 $0 \%$ 区の生重は, 処理開始時 $90 \mathrm{mg}$ であった が，7 日目には，220 mg，21 日目には $570 \mathrm{mg}$ で開始時 の 6.3 倍になった. 光混合栄養生長区における生重を, $0 \%$ 区の值に対する相対值で表すと，ショ糖濃度 $1 \%$ 区 では，7 日目に 1.1 倍，14 日目に 1.2 倍であったが， 21 日目になって 1.6 倍と $5 \%$ 水準で有意差がみられた。 シ ヨ糖濃度 $3 \%$ 区におケる生重は, 各測定日とも0\%区の 0.8 倍であった.

Table 3 に光合成測定に用いた小植物体の発根率およ び $S / R$ 生重比の変化を示す. 培地には発根促進のため

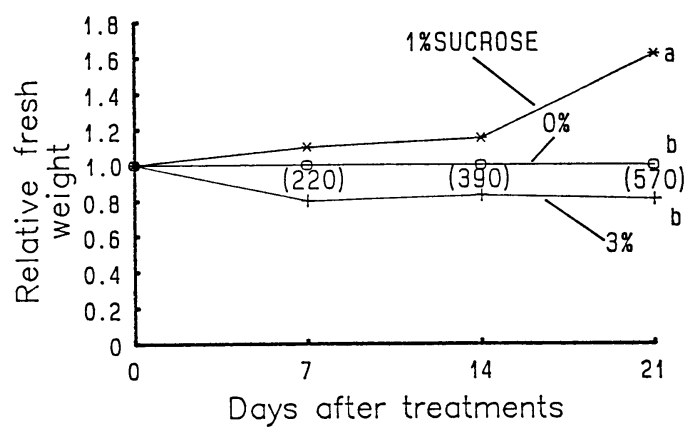

Fig. 2 Fresh weight of alfalfa plantlets cultured in vitro with different concentrations of sucrose in the medium.

Each value is relative to that with $0 \%$ sucrose $(=100 \%)$ same days after treatments. Values in parentheses indicate fresh weight $\left(\mathrm{mg} \cdot \mathrm{shoot}^{-1}\right)$ with $0 \%$ sucrose. Different letters indicate significant difference at $5 \%$ level in $t$ test.
の生長調節物質を添加しなかったが，処理 7 日目以降, 多くの小植物体の基部から発根がみられた. 14 日目の 小植物体の発根率は，0\%区で $73 \% ， 1 \%$ 区で $93 \%$ であ った． $3 \%$ 区では 21 日目でも $60 \%$ の発根率であった。 一方, 発根後はショ糖培地で根の生長が促進され, $S / R$ 比の值はショ糖培地で無糖培地に比べて小さくなった.

\section{3. 生長量と光合成速度}

小植物体の葉部のクロロフィル量（以下クロロフィル 量とする）とクロロフィル量当りの光合成速度（以下 $P_{\mathrm{Ch} 1}$ とする）との関係を用いて, 処理区間での小植物体 の光合成能を比較した (Fig. 3). クロロフィル量は単位 葉面積当りのクロロフィル含量に葉面積を乗じた值であ る. 各処理区ともクロロフィル量が増加するほど $P_{\mathrm{Ch} 1}$ は低下する傾向がみられた。ショ糖濃度 $0 \%$ 区での $P_{\mathrm{Ch} 1}$ は, 処理開始時, 7 日目および 14 日目とほぼ同じ值 $\left(3.3 \mathrm{mgCO}_{2} \cdot \mathrm{mgChl}^{-1} \cdot \mathrm{hr}^{-1}\right)$ を示し, クロロフィル量が $0.43 \mathrm{mg}$ となる 21 日目になって低下した. ショ糖濃度 $1 \%$ 区では処理 7 日目に開始時の 0.8 倍に低下したが, クロロフィル量が $0.41 \mathrm{mg}$ である 14 日目にはそれ以上

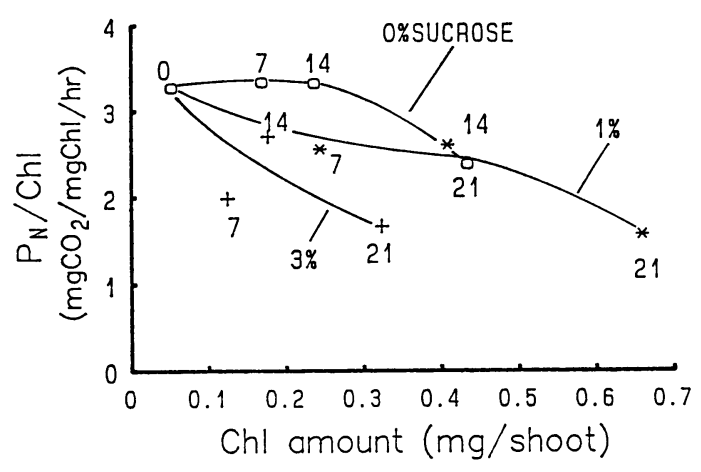

Fig. 3 Relationship between net photosynthetic rate $\left(P_{\mathrm{N}}\right)$ per chlorophyll (Chl) amount and $\mathrm{Chl}$ amount in leaves per plantlet. $P_{\mathrm{N}}$ was measured under $100 \mu \mathrm{mol} \cdot \mathrm{m}^{-2}$. $\mathrm{sec}^{-1}$ PPFD. Figures around the marks indicate days after treatments.

Table 3 Root initiation ratio and shoot/root ratio in fresh weight (S/R) of alfalfa plantlets cultured in vitro with different concentrations of sucrose in the medium.

\begin{tabular}{|c|c|c|c|c|c|c|}
\hline \multirow{2}{*}{$\begin{array}{l}\text { Days after treatments } \\
\text { Sucrose concentration }(\%)\end{array}$} & \multicolumn{3}{|c|}{14} & \multicolumn{3}{|c|}{21} \\
\hline & 0 & 1 & 3 & 0 & 1 & 3 \\
\hline Root initiation ratio (\%) & 73 & 93 & 50 & 80 & 80 & 60 \\
\hline$S / R$ ratio & 6.67 & 3.47 & 2.89 & 4.10 & 2.04 & 2.80 \\
\hline
\end{tabular}




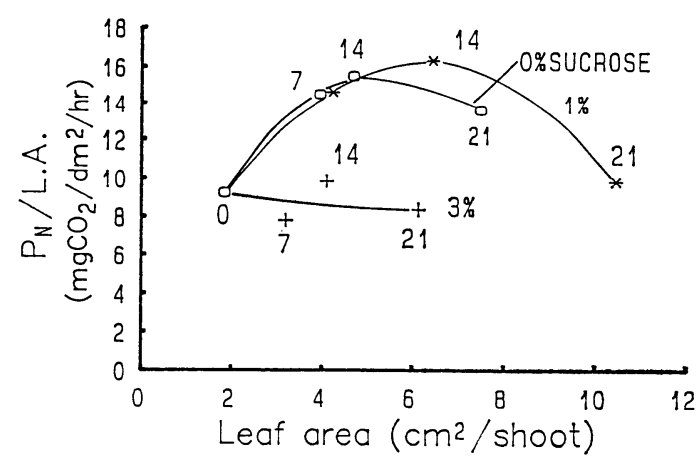

Fig. 4 Relationship between net photosynthetic rate $\left(P_{\mathrm{N}}\right)$ per unit leaf area and leaf area per plantlet.

$P_{\mathrm{N}}$ was measured under $100 \mu \mathrm{mol} \cdot \mathrm{m}^{-2}$. $\mathrm{sec}^{-1}$ PPFD. Figures around the marks indicate days after treatments.

の低下はみられず，クロロフィル量がほぼ同じ值である $0 \%$ 区 21 日目の $P_{\mathrm{Ch} 1}$ と同等な值を示した。 また， $3 \%$ 区ではクロロフィル量の增加にともなう $P_{\mathrm{Ch} 1}$ の低下が 著しかった。

次に，小植物体当りの葉面積と単位葉面積当りの光合 成速度（以下 $P_{\mathrm{LA}}$ とする）との関係を Fig. 4 に示す. ショ糖濃度 $0 \%$ 区での $P_{\mathrm{LA}}$ は, 処理開始時 $9.2 \mathrm{mgCO}_{2}$. $\mathrm{dm}^{-2} \cdot \mathrm{hr}^{-1}$ であったのが，葉面積の増加につれて 7 日目 には開始時の 1.6 倍, 14 日目には 1.7 倍で $15.5 \mathrm{mgCO}_{2}$. $\mathrm{dm}^{-2} \cdot \mathrm{hr}^{-1}$ と測定日中最も高い值を示し，21 日目に低下 した.ショ糖濃度 $1 \%$ 区でも $0 \%$ 区と類似の傾向を示 し，全葉面積が $6.4 \mathrm{~cm}^{2}$ となる 14 日目に $16.3 \mathrm{mgCO}_{2}$. $\mathrm{dm}^{-2} \cdot \mathrm{hr}^{-1}$ と最も高かった. Fig. 3 で夕られた $1 \%$ 区 7 日目での $P_{\mathrm{Ch} 1}$ の低下は, 単位葉面積当りのクロロフィ ル生成量（Table 2) の高い值を乗ずることによって打 ち消され， $P_{\mathrm{LA}}$ には差として現れなかった。また，3\% 区での $P_{\mathrm{LA}}$ は $0 \%$ 区と比べて著しく低く，処理開始時 から増加しなかった。

生重と光合成速度との関係（図示していない）におい ても同様の傾向が多られた.

一方, 生重と地上部暗呼吸速度との関係ではショ糖濃 度間での明白な違いはみられず,

$$
y=-5.83 \times 10^{-2} x-4.41 \times 10^{-4} \quad(r=0.97)
$$

で表される直線に近似され，Table 1 でみられた $1 \%$ 区 21 日目での高い暗呼吸速度は, 小植物体の生重の増加に よるものであった.ここで $x$ は生重 $(\mathrm{mg}), y$ は暗呼吸 速度 $\left(\mathrm{mgCO}_{2} \cdot \mathrm{shoot}^{-1} \cdot \mathrm{hr}^{-1}\right)$ を示す。
従属栄養の側面の強い条件で生長したアルファルファ 小植物体を切除して，その茎葉部を異なるショ糖濃度の 培地に植え付けると，ショ糖濃度 $1 \%$ の培地で，葉部で のクロロフィルの生成が処理 7 日目から促進され (Table 2)，葉面積が 14 日目に $0 \%$ 区の 1.4 倍になった (Fig. 1). クロロフィル量の増加にかかわる最適なショ 糖濃度は, 光混合栄養生長する細胞の培養あるいはカル スの培養で報告されており，タバコのカルスでは $0.3 \%^{10)}$ ，ジャガイモの細胞では $0.25 \%^{11)}$ であった。し かし，in vitro で光混合栄養生長する小植物体に関する 報告はみられない。

クロロフィル量当りの光合成速度は, ショ糖濃度 $1 \%$ で7日目に低下したが，これは，RuBP カルボキシラー ゼ活性の低下によるものかもしれない6).

一方，1\%区之0\%区では葉の生長に伴う単位葉面積 当りの光合成速度に差はみられなかった (Fig. 4). 同様 に，in vitro で培養したタバコの実生およびシュートの 単位葉面積当りの光合成速度は, ショ糖濃度 $2 \%$ および 0\%の培地で差が認められなかっだ5).

シュート当りの光合成速度は $1 \%$ 区で高くなる傾向が みられた(Table 1).これは, 葉面積の増加にともなう 単位葉面積当りの光合成速度が $0 \%$ 区と同様であり，乙 かも 14 および 21 日目に葉面積が $0 \%$ 区より有意に高く なったためである.したがって，処理開始から終了まで に $1 \%$ 区での小植物体は，同化産物を $0 \%$ 区之同等かあ るいはそれ以上に獲得して生長していたと考兄られる。

なお，培養器を同化箱として用いて光合成測定を行う 場合, その容積が小さいため, 流入空気の $\mathrm{CO}_{2}$ 濃度が 同一でも固定される $\mathrm{CO}_{2}$ の量の違いによって内部濃度 が異なる現象を無視できない，本実験では，PPFD 100 $\mu \mathrm{mol} \cdot \mathrm{m}^{-2} \cdot \mathrm{sec}^{-1}$ で内部濃度の違いが処理区間で最大 30 $\mathrm{ppm}$ と小さかったが，生長量がかなり異なる小植物体の 光合成速度を比較するような場合にはこのことを考慮す る必要があろう。

1\%区では小植物体の発根も0\%区と同様におこり (Table 3)，3\%区のような培地のショ糖による阻害的な 影響は認められなかった。 そして, 発根後の根の生長量 は高く，0\%区と比べて $S / R$ 比が小さかった (Table 3). また,アルファルファ実生を用いた実験でも， 2,000 ppm $\mathrm{CO}_{2}$ および $340 \mathrm{ppm} \mathrm{CO}_{2}$ 通気時においてショ糖濃度 $3 \%$ 区での根の生重および乾物重は，0\%区のそれより 高かった ${ }^{12)}$.

一方, $3 \%$ ショ糖培地での小植物体は, 光合成活性の 
低下や葉の黄化, 発根の遅延が認められ，21日目での生 長量も低かった。これは培地の水ポテンシャル ${ }^{13,14)}$ と関 連する生理的ストレスによるものかもしれない。

以上のことから次のことがいえる. 光混合栄養条件下 でのアルファルファ小植物体の培養において, 培地に与 えられた最適な濃度のショ糖は, 光独立栄養条件以上に 光合成器官の発達を促し, しかも葉面積の増加にともな う小植物体の光合成活性を阻害しなかった。そのため, 小植物体はショ糖を吸収し炭素源として生長するだけで なく，光合成産物を少なくとも光独立栄養生長区と同等 に獲得して生長していたであるう.

なお，本研究で用いた培養器内通気システムはフィル ターで滤過した無菌空気を通気することから培養中の微 生物による污染を防止できる。また, 培養器内部の空気 が流動することから葉面拡散抵抗が小さくなり光合成が 促進される可能性があり ${ }^{15)}$, 簡易培養装置として利用で きる。

\section{文献}

1）古在豊樹. 1988. 植物組織培養に上る種苗急速大量生産 における環境調節・「植物組織培養における環境調節」シ ンポジム 23-31.

2）古在豊樹· 久保田知恵利・渡部一郎. 1990. 異なる培地基 礎成分を用いて光独立栄養培養および光混合栄養培養した カーネーション小植物体の生長. 生物環境調節 28: 21-27.

3）古在豊樹・岩波好恵・富士原和宏. 1987. 炭酸ガス施用 が增殖培養時におけるスターチス (Limonium Hybrid) の小植物体の生長に及ぼす影響. 植物組織培養 4: 22-26.

4) Kozai, T., H. OKi, and K. Fujiwara. 1987. Effects of $\mathrm{CO}_{2}$ enrichment and sucrose concentration under high photosynthetic photon fluxes on growth of tissuecultured Cymbidium plantlets during the preparation stage. Symposium on Plant Micropropagation in Horti- cultural Industries. Arlon, Belgium 134-141.

5) Solarova, J., J. Pospisilova, J. Catsky, and J. SANTRUCEK. 1989. Photosynthesis and growth of tobacco plantlets in dependence on carbon supply. Photosynthetica 23: 629-637.

6）渡邊浩一郎・渡邊幸雄・嶋田典司. 1990. 通父培養にお けるスパティフィラム小植物体の生育, みかけの光合成お よびリブロース-1,5-二リン酸カルボキシラーゼに及ぼす 培地ショ糖濃度の影響について。植物組織培養 7: 74-79.

7) Murashige, T. and F. Skoog. 1962. A reversed medium for rapid growth and bioassays with tobacco tissue cultures. Physiol. Plant. 15: 473-497.

8）清田 信. 1987. 光合成速度 - 呼吸速度の測定. 1 同化箱 法による測定.「農業環境実験法」(渡部一郎編) 99-105, サイエンスハウス, 東京.

9) Arnon, D. I. 1949. Copper enzymes in isolated chloroplasts. Polyphenoloxidase in beta vulgaris. Plant Physiol. 24: 1-15.

10) Cseplo, A. and P. Medgyesy. 1986. Characteristics symptoms inhibition by harbicides are expressed in photomixotrophic tissue cultures of Nicotiana. Planta 168: 24-28.

11) LaRosa, P. C., P. M. Hasegawa, and R. A. Bressan. 1984. Autotrophic potato cells: Transition from heterotrophic to autotrophic growth. Physiol. Plant. 61: 279-286.

12）清田 信 - 谷 晃 - 平 知朋 - 相賀一郎. 1989. in vitro でのアルファルファ実生抢よびシュート培養幼植物 体の成長におよぼす二酸化炭素, 光, 糖の影贸. 日本農業 気像学会近畿支部大会講演要吕: 13-14.

13) Brown, D.C.W., D. W. M. Leung, and T. A. Thorpe. 1979. Osmotis requirement for shoot formation in tobacco callus. Physiol. Plant. 46: 36-41.

14) Kimball, S. L., W. D. Beversdorf, and E. T. BINGHAM. 1975. Influence of osmotic potential on growth and development of soybean tissue cultures. Crop Sci. 15: 750-752.

15）矢吹萬壽. 1.985. 葉面拡散抵抗. 「植物の動的環境」111130, 朝倉書店, 束京. 